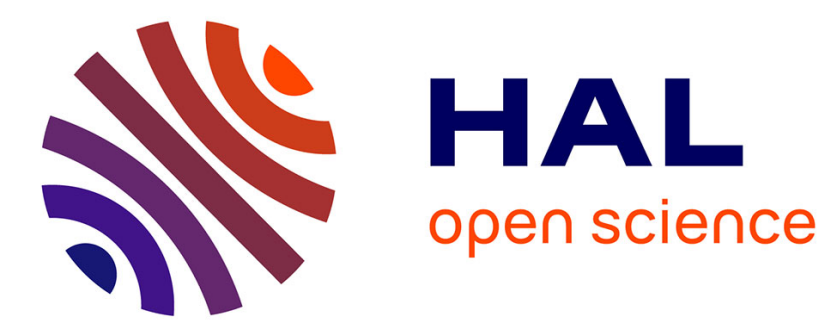

\title{
Internal structuring of silicon by ultrafast laser irradiation \\ David Grojo
}

\section{To cite this version:}

David Grojo. Internal structuring of silicon by ultrafast laser irradiation. OSA Technical Digest (Optical Society of America), 2019, pp.CM_2_1. hal-02990081

\section{HAL Id: hal-02990081 \\ https://hal.science/hal-02990081}

Submitted on 5 Nov 2020

HAL is a multi-disciplinary open access archive for the deposit and dissemination of scientific research documents, whether they are published or not. The documents may come from teaching and research institutions in France or abroad, or from public or private research centers.
L'archive ouverte pluridisciplinaire HAL, est destinée au dépôt et à la diffusion de documents scientifiques de niveau recherche, publiés ou non, émanant des établissements d'enseignement et de recherche français ou étrangers, des laboratoires publics ou privés. 


\title{
Internal structuring of silicon by ultrafast laser irradiation
}

\author{
David Grojo \\ Aix-Marseille University, CNRS, LP3 UMR 7341, Marseille, France
}

\begin{abstract}
Recent demonstrations of internal structuring of silicon have open new perspectives for the important field of three-dimensional ultrafast laser writing. We discuss the applied methodologies and the remaining challenges to address microfabrication applications in silicon.
\end{abstract}

An important challenge in the field of three-dimensional (3D) ultrafast laser processing is to achieve permanent modifications in the bulk of silicon ( $\mathrm{Si}$ ) and narrow-gap materials. Attempts by increasing the energy of infrared femtosecond pulses with conventional laser machining configurations have failed [1]-[3].

This paper concentrates on the limitations experienced in femtosecond interactions at 1300-nm wavelength to fully identify their origins. We present experimental investigations on the $3 \mathrm{D}$ reconstruction of the nonlinear pulse propagation and ionization of Si under tight focusing configurations. By comparison with simulations [4], we quantify the strong nonlinear and plasma effects in the pre-focal region causing the limitations [5]. With an extrapolation on the energy density that could be delivered with hyper-NA values (up to 3.5 in $\mathrm{Si}$ ), we show that solid immersion focusing provides a solution to achieve ultrafast optical breakdown in Si [5]. By repeatedly illuminating the center of a Si sphere with pulses focused at apparent NA near 3, we exceed the breakdown threshold with sub-100 fs pulses. This leads to a highly-localized negative change of the refractive index as measured with an infrared phase microscopy arrangement. Beyond this proof-of-concept demonstration, the experiment can be translated with the astigmatic solid-immersion lens (ASIL) configuration consisting in focusing the laser radiation through an hemispherical Si sample while ensuring an appropriate optical contact with a planar wafer. This makes possible to achieve similar modifications in Si wafers with a long working distance focusing objective of modest NA $(<0.3)$. It represents a critical step towards the fabrication of 3D photonic microdevices in silicon by a laser writing method.

Another practical solution is to rely on longer pulses in the picosecond regime to reduce the peak power and the associated nonlinear effects limiting the energy delivery [6]-[8]. Compared to femtosecond lasers, the experiments confirm that picosecond sources lead to reduced thresholds for 3D writing inside silicon that is highly desirable. However, strong interplays between nonlinear effects persist and should not be ignored for the performance of the future technological developments. We illustrate this aspect by carefully retrieving from a studied case (2-ps pulses at 2- $\mu \mathrm{m}$ wavelength) the conditions for a demonstration of 3D data inscription inside a silicon wafer [9].

Despite the difficulties, refractive index engineering by ultrafast laser writing has the potential to make possible 3D architectures and monolithic Si platforms for the important field of Silicon Photonics. More generally, these developments have the potential to change the way silicon-based microsystems are today designed and fabricated.

\section{Acknoweledgments}

This project has received funding from the European Research Council (ERC) under the European Union's Horizon 2020 research and innovation program (Grant Agreement No. 724480).

\section{References}

[1] V. V Kononenko, V. V Konov, and E. M. Dianov, "Delocalization of femtosecond radiation in silicon,” Opt. Lett., vol. 37, no. 16, pp. 3369-71, 2012.

[2] A. Mouskeftaras, A. V. Rode, R. Clady, M. Sentis, O. Utéza, and D. Grojo, "Self-limited underdense microplasmas in bulk silicon induced by ultrashort laser pulses," Appl. Phys. Lett., vol. 105, p. 191103, 2014.

[3] D. Grojo, A. Mouskeftaras, P. Delaporte, and S. Lei, "Limitations to laser machining of silicon using femtosecond micro-Bessel beams in the infrared," J. Appl. Phys., vol. 117, no. 15, p. 153105, 2015.

[4] V. Y. Fedorov, M. Chanal, D. Grojo, and S. Tzortzakis, “Accessing Extreme Spatiotemporal Localization of High-Power Laser Radiation through Transformation Optics and Scalar Wave Equations," Phys. Rev. Lett., vol. 117, no. 4, p. $043902,2016$.

[5] M. Chanal, V. Y. Fedorov, M. Chambonneau, R. Clady, S. Tzortzakis, and D. Grojo, "Crossing the threshold of ultrafast laser writing in bulk silicon," Nat. Commun., vol. 8, no. 1, p. 773, 2017.

[6] H. Kämmer, G. Matthäus, S. Nolte, M. Chanal, O. Utéza, and D. Grojo, "In-volume structuring of silicon using picosecond laser pulses," Appl. Phys. A, vol. 124, p. 124:302, 2018

[7] G. Matthäus, H. Kämmer, K. A. Lammers, C. Vetter, W. Watanabe, and S. Nolte, "Inscription of silicon waveguides using picosecond pulses," vol. 26, no. 18, pp. 4875-4878, 2018.

[8] I. Pavlov et al., "Femtosecond laser written waveguides deep inside silicon," Opt. Lett., vol. 42, no. 15 , p. $3028,2017$.

[9] M. Chambonneau et al., "Competing nonlinear delocalization of light for laser inscription inside silicon with a 2- $\mu$ m picosecond laser," Unpublished, 2019. 